\title{
LTB-R1: AN ALTERNATIVE TO SWINE MYCOPLASMAL PNEUMONIAE CONTROL
}

\author{
Fabrício Rochedo Conceição ${ }^{1 *}$; André Michelon ${ }^{1,2}$; Marcelo Michelon ${ }^{1}$; Gustavo Maia de Cerqueira ${ }^{1}$; \\ Odir Antonio Dellagostin ${ }^{1}$
}

${ }^{1}$ Centro de Biotecnologia, Universidade Federal de Pelotas, Pelotas, RS, Brasil. ${ }^{2}$ Programa de Pós-Graduação em Veterinária, Universidade Federal de Pelotas, Pelotas, RS, Brasil.

This paper corresponds to an "extended abstract" selected for oral presentation in the $22^{\text {nd }}$ Brazilian Congress of Microbiology, held in Florianópolis, SC, Brazil, in November 17-20, 2003

\begin{abstract}
Mycoplasmal pneumoniae is the main respiratory disease in swine. The most efficient way to control it is through the use of vaccines (bacterins), whose production cost is high. The objective of this work was to develop a new alternative for controlling Swine Mycoplasmal Pneumoniae, based on a recombinant subunit vaccine containing the R1 region of P97 adhesin of Mycoplasma hyopneumoniae fused to the B subunit of the heat-labile enterotoxin of Escherichia coli (rLTB-R1). In this work we report the amplification of the genes, genetic fusion between LTB and R1 coding sequences, cloning, construction of the expression vector, as well as expression and purification of rLTB-R1 in E. coli.
\end{abstract}

Key words: swine mycoplasmal pneumoniae, P97, LTB.

\section{INTRODUCTION}

Swine Mycoplasmal Pneumoniae (SMP), caused by Mycoplasma hyopneumoniae, is the most important respiratory disease in swine breeding. Economic losses, as a result of lower productivity can represent around $20 \%$ in lower food conversion and $30 \%$ in weight loss, depending on the severity of lesions and secondary infections (2).

The commonly used vaccines to SMP control consist of killed bacterial cells (bacterins). However, growth of $M$. hyopneumoniae "in vitro" requires a rich media, and it is a time consuming process, which makes the final cost of this vaccine very expensive (1). As a result, vaccines developed using recombinant DNA technology become a viable alternative. In order to induce local protective immunity, this vaccine candidates need a good adjuvant. Heat-labil enterotoxin B subunit from Vibrio cholerae and Escherichia coli (CTB and LTB) have been evaluated as molecular adjuvants. These nontoxic subunits are potent mucosal adjuvants, stimulating a strong systemic response and a secretory response of antibodies against co-administrated antigens (3).

The goal of this project was to construct an expression plasmid encoding the $\mathrm{R} 1$ region of $\mathrm{P} 97$ antigen, an adhesin from M. hyopneumoniae, fused to the heat-labil enterotoxin B subunit from E. coli, This fusion protein was expressed, purified and further characterized, remaining to be evaluated as a recombinant subunit vaccine in animal models.

\section{MATERIALS AND METHODS}

The $\mathrm{r} 1$ gene sequence which is found within the $\mathrm{p} 97$ gene and the gene encoding the LT-B subunit were both amplified by PCR using Platinum ${ }^{\circledR}$ Pfx DNA Polymerase (Invitrogen). Primers for $l t-b$ and $r l$ amplification were designed based on GenBank $^{\mathrm{TM}}$ sequences, found under access numbers M17873 and U50901, respectively. The $l t-b$ reverse primer and the $r 1$ forward primer were modified allowing a Bam $\mathrm{HI}$ restriction site insertion for the correct reading frame fusion of the 3 ' end of $l t$ -

*Corresponding author. Mailing address: Centro de Biotecnologia, Universidade Federal de Pelotas. Caixa Postal 354. 96010-900, Pelotas, RS, Brasil. E-mail: frochedo@ufpel.tche.br 
$b$ with the 5' end of $r 1$. This approach allowed direct fusion of the genes after restriction digestion and ligation of the PCR products. The lt-b forward primer had a CACC sequence at the 5' end, which directs the cloning the fragment within pENTR/ SD cloning plasmid (Gateway system - Invitrogen). After PCR amplification, both products were purified from agarose gel using GFX Gel band purification system (Amershan Biosciences), digested using BamHI restriction endonuclease, precipitated, purified using phenol-chloroform procedure and fused using T4 DNA ligase enzyme (Invitrogen). A new PCR reaction using $P f x$ DNA polymerase enzyme was performed. This reaction used the $l t-b$ forward and $r l$ reverse primers for amplification of the fused $l t b-r l$ fragments. After $l t b-r l$ cloning in $\mathrm{pENTR} / \mathrm{SD}$, a site-specific recombination reaction was performed using the LR-Clonase ${ }^{\mathrm{TM}}$ enzyme (Invitrogen). This reaction transferred the insert from the pENTR/SD cloning vector to the pETDEST42 ${ }^{\mathrm{TM}}$ expression vector. E. coli DH5a competent cells were transformed with the expression plasmid containing the ltb-r1 insert to generate expression clones. The transformation was plated on LB containing $100 \mathrm{mg} / \mathrm{ml}$ ampicilin. The construct pDEST42-LTB-R1 was extracted and used to transform BL21 SI competent $E$. coli cells, which were inoculated in 2YT-ON media and incubated in a shaker $\left(30^{\circ} \mathrm{C} / 250 \mathrm{rpm}\right)$ until reaching $\log$ phase peak when expression of the recombinant protein was induced using $\mathrm{NaCl} 300 \mathrm{mM}$ and IPTG $1 \mathrm{mM}$. At $4 \mathrm{~h}$ after induction the culture was centrifuged at $6000 \mathrm{xg}$, the supernatant was discarded and the pellet was resuspended and sonicated. The purification procedure was performed following QIAEXPRESS system (Qiagen) instructions. The recombinant protein rLTB-R1 was characterized by Western blot using anti$\mathrm{IgG}$ antibody against choleric toxin from immunized rabbits (Sigma).

\section{RESULTS}

The PCR amplification of $r l$ sequence (280 bp) and ltb gene (320 bp) is shown in Fig. 1. The PCR amplification of the fused genes $l t b-r l$ resulted in a $600 \mathrm{bp}$ fragment (Fig. 1). The fused genes were cloned in $\mathrm{pENTR/SD} \mathrm{cloning} \mathrm{vector} \mathrm{and} \mathrm{transferred}$ to pDEST42 expression vector. The recombinant protein rLTBR1 (25 kDa) was detected by Western blot using IgG antibody from rabbit immunized with choleric toxin. Two distinct bands appeared on the blot (Fig. 2). The rLTB-R1 purification was performed following the QIAEXPRESS system instructions, which provided a good purification, enough to remove all BL21 (DE3) SI E. coli proteins (Fig. 3).

\section{DISCUSSION}

pDEST42-LTB-R1 plasmid expressed the conjugated recombinant protein fused to a $6 x$ Histidine tag allowing affinity chromatography column purification. Western blot and SDS-

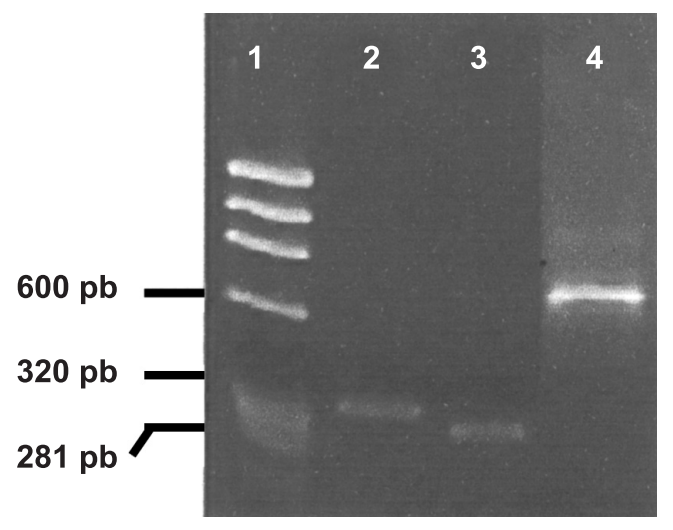

Figure $1-1.5 \%$ agarose gel containing the PCR products, amplified by Pfx DNA polymerase enzyme 1- $\phi \mathrm{X}-174$ molecular mass ladder; 2- ltb; 3- $r 1$; 4-ltb-rl.

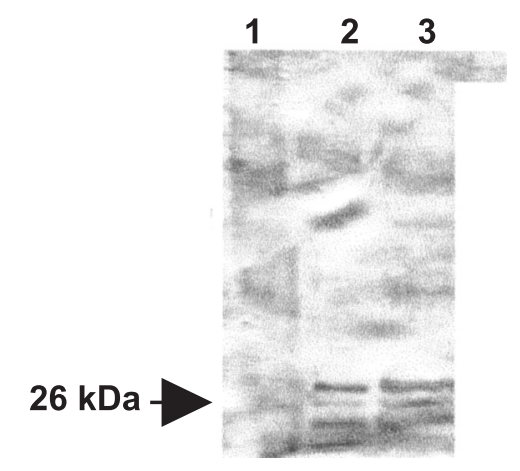

Figure 2. Western blot demonstrating that proteins are recognized by IgG antibody from rabbit immunized with choleric toxin 1 - Prestained Ladder (Invitrogen); 2 - choleric toxin (5 $\mu \mathrm{g}) ; 3$-rLTB-R1.

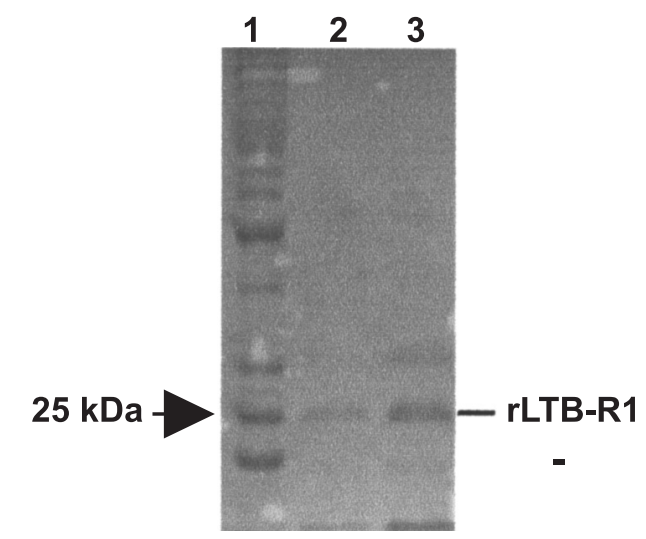

Figure 3. 12\% SDS-PAGE demonstrating the recombinant rLTBR1 protein purification by affinity chromatography column (QIAExpress-Qiagen). 1- Protein Ladder (Invitrogen); 2- rLTBR1 $1^{\text {st }}$ elution; 3-rLTB-R1 $2^{\text {nd }}$ elution. 
PAGE revealed 2 bands, a lower band around $25 \mathrm{kDa}$, corresponding to rLTB-R1 protein and a higher band around 30 $\mathrm{kDa}$. This second and higher band is thought to be protein polimerization, once heat-labil enterotoxin B subunit shows a pentameric polimerization property. Gateway system made easy and fast the expression vector construction by avoiding steps usually taken such as digestion, dephosphorilation and ligation. Moreover, inserts were always found in the correct orientation. We have described here the amplification by PCR, gene fusion, cloning and expression of rLTB-R1, a recombinant subunit vaccine that will be evaluated regarding its capacity to induce protective immunity in swine.

\section{RESUMO}

\section{LTB-R1: uma alternativa para o controle da pneumonia micoplásmica suína}

A Pneumonia Micoplásmica é a doença respiratória mais importante dos suínos. A forma mais eficaz de controlá-la é mediante a utilização de vacinas (bacterinas), cujo custo de produção é elevado. Uma nova alternativa para o controle desta doença, baseada em uma vacina de subunidade recombinante contendo a região R1 da adesina P97 de Mycoplasma hyopneumoniae fusionada a subunidade $\mathrm{B}$ da enterotoxina termolábel de Escherichia coli (rLTB-R1), foi o alvo deste trabalho. Nele abordou-se a amplificação dos genes, a fusão genética entre as seqüências codificadoras para LTB e R1, a clonagem, a construção do vetor de expressão, assim como a expressão em $E$. coli e purificação da rLTBR1.

Palavras-chave: pneumonia micoplásmica suína, P97, LTB.

\section{REFERENCES}

1. Chen, J.R.; Liao, C.W.; Mao, C.N.W. A recombinant chimere composed of repeat region RR1 of Mycoplasma hyopneumoniae adhesin with Pseudomonas exotoxin: in vivo evaluation of specific IgG response in mice and pigs. Vet. Microbiol., 80:347-357, 2001 .

2. Sobestiansky, J.; Barcellos, D.; Mores, N.. Pneumonia enzoótica. In: Clínica e Patologia Suína. $2^{\text {a }}$ ed., Art 3 Impressos Especiais, Goiânia, Goiás, p.359, 1999.

3. Verweij, W.R.; Haan, L.; Holtrop, M. Mucosal immunoadjuvant activity of recombinant Escherichia coli heat-labile enterotoxin and its B subunit: Induction of systemic IgG and secretory IgA responses in mice by intranasal immunization with influenza virus surface antigen. Vaccine, 16:3476-3482, 1998 